\title{
The Degree of Relationships and Differences Among Level of ICT Utilization in Instruction and Lectures' Demographic Factors in Selected Universities of Pakistan
}

\author{
Dr. Shahbaz Ahmad \\ Assistant Professor, Department of Education \\ University of Lahore, Sub-Campus, Sargodha \\ shahbaz.ahmad@ed.uol.edu.pk
}

\begin{abstract}
The ICT (Information \& Communications Technology) utilization in instruction among university and college lecturers is gaining prominence in many countries in the world, including Pakistan, for the purpose of globalization and enhancing the quality of instruction and learning. The purpose of the study was to examine the benefits of ICT utilization, the extent of success factors, problems and constraints encountered in ICT utilization in instruction among lecturers in universities of Islamabad. A cross-sectional questionnaire survey was used to find out the level and extent of ICT utilization in universities of Islamabad. The sample from the study consisted of 260 lecturers drawn from the 14 universities of Islamabad. The data were analyzed using descriptive statistics and inferential statistics such as Pearson correlation, and chi square. Results of the study showed that there were significant relationships among the 14 areas of ICT utilization, significant relationships between ICT utilization and lecturers' characteristics, and significant relationships between ICT utilization and university demography. There were positive correlations between ICT utilization and some demographics such as lecturers' age, working experience, experience in computer use, frequency of ICT use, computer use at home, ICT training duration, extent of ICT knowledge, awareness of ICT and ICT written / published in university. The findings of this study could be used for improving instruction among lecturers and for designing a training model for instruction among lecturers in the pursuit of enhancing excellence and quality of education in universities. This study was subjected to several limitations that include online assessment, incorporating audio video conferencing tools, giving more sophistication to educational management software.
\end{abstract}

\section{Introduction}

The use of quality ICT has become the most basic and advanced industrial society in a little time. Getting expert in ICT and knowing the basic command along with skills and concepts of Information and Communication Technology are given high respect and importance in many countries. Information and Communication Technology are being utilized at a very high rate in quality learning and teaching for student success especially by the lecturers. This study endeavors to measure the extent of ICT available, its utilization levels, determine the relationship between extents of technology utilization with university characteristics and instruction among lecturers' characteristics, amount of budget spent and factors affecting ICT utilization in instruction among lecturers of capital universities.

Jones and Preece (2006) reported that online learners (and lecturers) need to learn to "trust the technology" for technological performance as well as enhance the uptake and reduce resistance to technology. Lecturers need to be confident and competent in using various ICT tools to build their trust in the technology. Without their competency and mastery skills of ICT utilization appropriate to their needs, ICT could not be put into good use for instructional delivery. Barker 
(2001) stated that this should possess a range of multiple communication and technical skills along with using the chat rooms, web page authoring, word processing skills and using different kinds of Information and Communication Tools like File Transfer Protocol (FTP), compress and decompress of files, e.g., Win zip etc.

Technology can be helpful in decreasing absenteeism, lower dropout rates and motivate more students to continue on to university. Students take more pride in their work while using technology, gain more confidence in their abilities, and develop a higher level of self-esteem. Furthermore, researchers have mentioned that ICT utilization in instruction among lecturers alleviates many teaching difficulties, controlling and administrating large number of students, and teachers express positive opinion about it (Altun, 1996). Most universities seem not yet ready to implement ICT utilization. The reason for this low uptake may vary from university to university. Generally speaking, some of the more prominent constraints include, among other things, substandard technology infrastructure delivery and support; low funding; failure to localize technologies; low levels of instruction among lecturers / facilitators' expertise and / or commitment coupled with a shortage of educational technology, instructional design, and learning development staff; low levels of student accessibility to the Internet; bandwidth availability and / or accessibility; and non-suitability of academic content and goals to such designs. Thus, in order to keep lecturer and trainers updated with current technological changes, related studies on technological utilizations should be conducted on a regular basis as well.

This study is carried out to analyze ICT utilization necessary for instruction among lecturers of the capital universities of Pakistan. Chen (1995) investigated the perceptions and network performance in Taiwan. In addition, he reported that overall network staff and lecturers' perceptions toward network organization (NBINET) were not quite positive. The major factors in lecturers' negative perceptions were: inability of the governing body to carry out its policies, added workload, slow response, limited number of skilled technicians, lack of motivation, and dissatisfaction with the hit rate. Chen further investigated the feasibility of the establishment of an information-sharing network in Riyadh, Saudi Arabia and found that the existing cooperative activities among Saudi universities were ineffective and inadequate.

He determined a number of factors hindering cooperation including lack of comprehension of the value of such a network, lack of standardization in technical processing, limitation of financial resources, lack of initiative of professional associations, and administrative problems. Chen suggested the exploitation of Internet to implement cooperative networks for physical linkage and to consider the human factor as the most critical for its implementation. It was discovered that the variables most often identified as contributing to receptivity or resistance to changes is:

- Members' participation in decision-making and implementation

- Perceived availability of training and skills enhancement opportunities

- Presence of entrepreneurs

- Gender and age-related issues

- Prior experience with technology

- Specialization within the organization

- Degree of professionalism within the organization

- Organizational slack

- Fear of technology in general and computers in particular

- Fear of changes

- Perceived threats to job security or status 
- The distribution of expertise

- The presence or absence of feedback and interaction

- Unionization

- Patterns of hiring and rewarding employees

This study discovered the overall positive perceptions toward ICT utilization in instruction in universities. Most of the demographic variables studied such as gender, age, and the highest degree obtained, functional areas of instruction among lecturers, and length of experience were not significantly related to individuals' perceptions toward computers. The transfer from print to online education formats was inevitable but would take place gradually, because of the shortage of trained human resources, and ICT tools. Chen suggested that training of lecturers keep pace with ICT developments and changes. He stated that lecturers should not fear computers and should take them as tools to help in different operations. Lecturers' training should shift to computer science and application of computer technology in universities.

Khan (2005) mentioned that the changes occurring due to ICT application would affect the instructors' role. He pointed out that basic functions of information would remain the same, but the methodology and formats of information would change drastically. Wilkins (1999) reported that the educational environment would continue to be influenced by technology and users' needs. It would be governed by global policies that would ensure access to information for a diverse community. The lecturer was seen as playing a role of tutor, mentor, coach and client / student consultant.

\section{Research Questions}

The following research question was designed to achieve the objectives of the study:

- What are the extents of relationships and differences among the level of ICT utilization in instruction among lecturers' demographic factors?

\section{Theoretical Framework}

In studying user acceptance and technology use, the Technology Acceptance Model (TAM) is one of the most cited models. The TAM was developed by Davis to explain computerusage perception. The theoretical basis of the model was Fishbein and Ajzen's Theory of Reasoned Action (TRA). The Technology Acceptance Model (TAM) is an information system (System consisting of the network of all communication channels used within an organization) theory that models how users come to accept and use a technology. The model suggests that when lecturers are presented with a new software package, a number of factors influence their decision about how and when they will use it, notably: Perceived usefulness (PU), defined by Fred Davis as "the degree to which a person believes that using a particular system would enhance his or her job performance" and Perceived ease-of-use (PEOU) defined by Davis as "the degree to which a person believes that using a particular system would be free from efforts" (Davis, 1989).

Task-technology fit (TTF) theory holds that ICT is more likely to have a positive impact on individual performance and be used if the capabilities of the ICT match the tasks that the lecturer must perform (Goodhue \& Thompson, 1995). Goodhue and Thompson (1995) developed a measure of task-technology fit that consists of 8 factors: quality, locate ability, authorization, 
compatibility, ease of use / training, production timeliness, systems reliability, and relationship with lecturers.

Self-efficacy is people's perception of their ability to plan and take action to reach a particular goal. Computer self-efficacy (CSE) refers to individuals' judgment of their capabilities to use computers in diverse situations. Computer Self-Efficacy (CSE) constructs is a specialized definition referring to peoples' belief in their ability to accomplish a special task. The concept of SE was developed by Bandura (1986) from the social cognition literature. Bandura noted that SE is affected by past experience, observing others, persuasion and affective arousal.

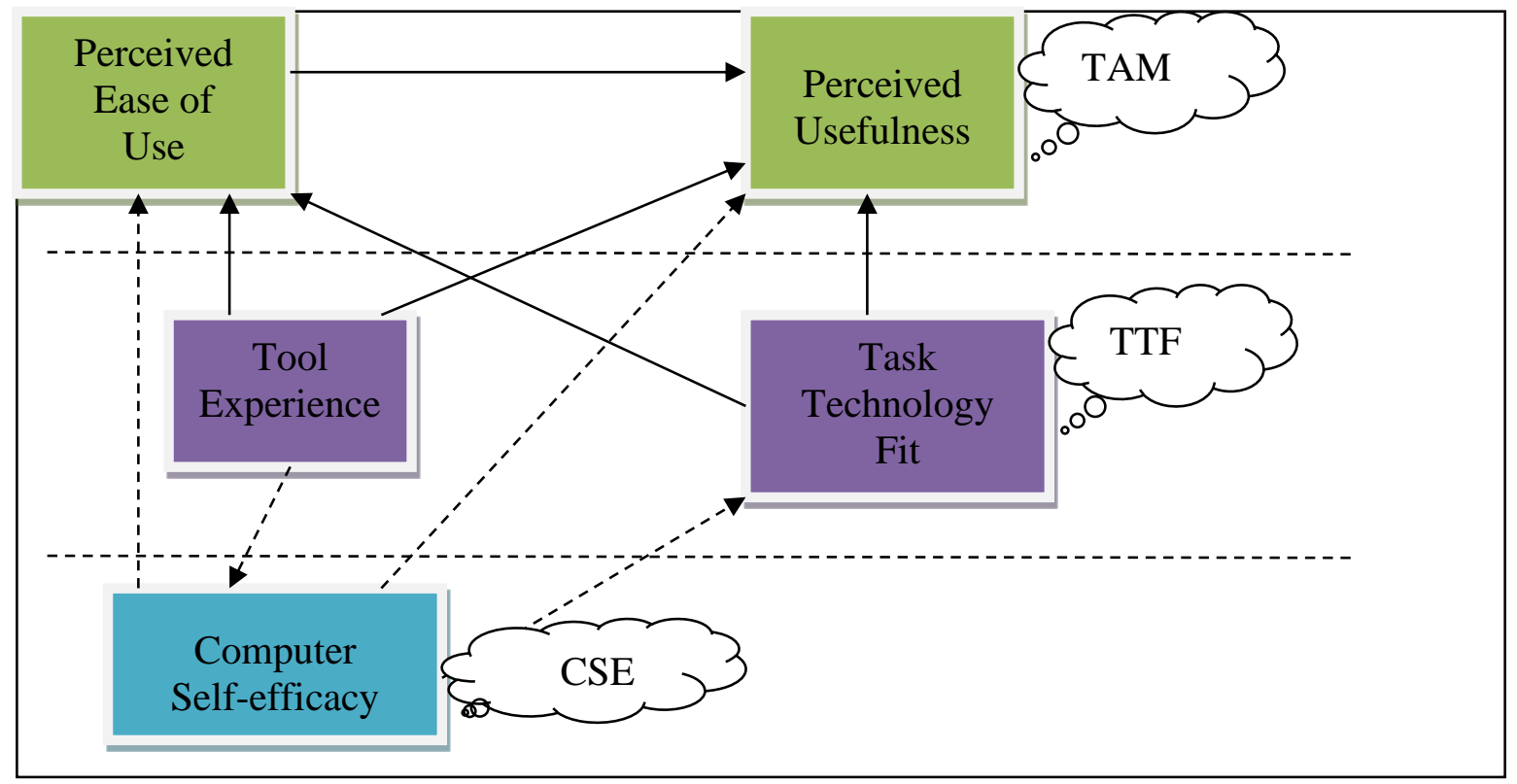

Theories on ICT utilization in instruction / instructional effectiveness

Source: TAM (Davis 1989), TTF (Goodhue, 1995), and CSE (Bandura 1986)

\section{Research Methodology}

The subjects for this study were the lecturers working in selected universities of Pakistan. The lecturers were chosen to complete the questionnaire because they were assumed to be the most influential personnel involved in decision-making, obtaining funds, devising ICT innovations, initiating ICT in instructional proposals and implementing ICT utilization and technology developments in their universities. It has also been acknowledged that lecturers' have key role in initiation, getting resources and utilizing ICT in instruction in universities. The researcher reviewed the literature of user surveys for studies to identify a model survey instrument that could be adopted completely. A comprehensive questionnaire was developed to answer the research question. The questionnaire was designed using mostly closed-ended/structured questions, check boxes and Likert type rating scale. ICT is easy for respondents to answer the structured questions and easy for the researcher to analyze and interpret. Factual, opinions and perception, informative and self-perception type questions were used to obtain the required information. A perception rating scale yields a single score that indicates both the direction and intensity of a person's perception. ICT helps differentiate those respondents with strongly agree perception from those 
with strongly disagree perception. These categories enable the users to make a choice from a range of possible values in questionnaires (Henerson et al., 1987). Likert's perception measuring technique helps to represent an individual's perception toward an object, using one preference score or average "most acceptable" position on a continuum of positions, which range from strongly agree to strongly disagree. Pickard (2007) identified that the Likert technique is popular to measure perception because ICT is simple and reliable. Based on the above discussion and recommendations, the researcher decided to use the Likert type scale to measure the perception of lecturers toward information and communication technology.

\section{Data Collection}

A survey questionnaire was used as an instrument to obtain primary data from the lecturers of selected universities of Pakistan. The survey questionnaire method is commonly used to investigate the status of tools, techniques and applications, changes over a certain period of time, opinions and characteristics of individuals and characteristics of universities. After pretesting and pilot study, the final questionnaire was prepared and mailed to 850 sampled lecturers working in universities in Islamabad, Sargodha and Lahore, Pakistan.

The questionnaire was accompanied by a cover letter as well as a self-addressed return envelope requesting completion and return of the questionnaire as soon as possible. The cover letter is appended in Appendix C. Given the low response rate in mail surveys, a number of steps were taken to improve the response rate. These steps included:

- Two reminders were made, using email / telephones

- The target respondents were also reminded personally as well as through professional colleagues and friends across Islamabad.

- Personal visits and follow-up calls were also made to some respondents for confirmation of some of the information they provided in the questionnaire and to ensure that the questionnaire was filled by the intended respondents. Out of 850 questionnaires administered, 269 (31.64\%) completed questionnaires were received. However, in 9 questionnaires, a major part of the ICT utilization and demographic information was incomplete. Finally, 260 (30.58\%) questionnaires were used for data analysis and interpretation.

\section{Association and Differences among the fourteen areas of ICT Utilization and Lecturers Characteristics}

The analyses in this section are to answer research question 3: What are the extents of associations and differences among the level of ICT utilization in instruction among lecturers' demographic factors?

Chi-square association values are to indicate the degree of association, whereas the covariance values are to indicate the degree of differences among the fourteen areas of ICT utilization. The following detail showed the relationship and differences of fourteen areas of ICT utilization and fourteen characteristics of instruction among lecturers in selected universities in Pakistan.

The Table ( $\mathrm{a} \& \mathrm{~b}$ ) showed the associations and differences among the 14 aspects of ICT utilization with the characteristics of lecturers. 
International Journal of Distance Education and E- Learning (IJDEEL) Volume VI- Issue II (June 2021)

Table a: Associations \& Differences of ICT Utilization with Lecturers' Characteristics

\begin{tabular}{|c|c|c|c|c|c|c|c|c|c|}
\hline Areas of ICT & & $\begin{array}{c}\text { Computer } \\
\text { Management }\end{array}$ & $\begin{array}{c}\text { H/W } \\
\text { Environment }\end{array}$ & $\begin{array}{c}\text { Word } \\
\text { Processing }\end{array}$ & Spreadsheet & Database & Presentation & $\begin{array}{c}\text { Use } \\
\text { Internet }\end{array}$ & $\begin{array}{c}\text { Use } \\
\text { Intranet }\end{array}$ \\
\hline \multirow[t]{3}{*}{ Qualification } & $\begin{array}{l}\text { Pearson Chi- } \\
\text { Square }\end{array}$ & 89.015 & 119.149 & 133.070 & 156.764 & 139.202 & 138.485 & 200.225 & 62.633 \\
\hline & Sig. (2-tailed) & 0.776 & 0.304 & 0.648 & 0.107 & 0.042 & 0.425 & 0.000 & 0.525 \\
\hline & Covariance & 0.214 & 0.089 & 0.464 & 0.448 & 0.014 & 0.357 & 0.506 & 0.034 \\
\hline \multirow[t]{3}{*}{ Last Qualification } & $\begin{array}{ll}\text { Pearson } & \text { Chi- } \\
\text { Square } & \end{array}$ & 89.015 & 106.087 & 121.206 & 171.927 & 111.535 & 104.343 & 72.991 & 60.885 \\
\hline & Sig. (2-tailed) & 0.771 & 0.640 & 0.872 & 0.020 & 0.495 & 0.980 & 0.875 & 0.587 \\
\hline & Covariance & -0.130 & -0.244 & 0.077 & -0.443 & -0.049 & 0.076 & -0.046 & 0.109 \\
\hline \multirow[t]{3}{*}{ Age } & $\begin{array}{l}\text { Pearson Chi- } \\
\text { Square }\end{array}$ & 135.196 & 142.417 & 180.767 & 171.888 & 113.970 & 169.310 & 108.449 & 75.075 \\
\hline & Sig. (2-tailed) & 0.251 & 0.427 & 0.367 & 0.445 & 0.948 & 0.501 & 0.524 & 0.635 \\
\hline & Covariance & -0.152 & -0.148 & 0.310 & -0.576 & -0.407 & 0.304 & 0.104 & -0.060 \\
\hline \multirow[t]{3}{*}{ Gender } & $\begin{array}{l}\text { Pearson } \quad \text { Chi- } \\
\text { Square }\end{array}$ & 53.123 & 67.238 & 80.321 & 81.792 & 68.049 & 90.049 & 43.705 & 87.370 \\
\hline & Sig. (2-tailed) & 0.974 & 0.910 & 0.955 & 0.930 & 0.897 & 0.795 & 0.984 & 0.000 \\
\hline & Covariance & -0.044 & -0.189 & 0.188 & 0.076 & 0.103 & 0.022 & 0.052 & -0.004 \\
\hline \multirow[t]{3}{*}{$\begin{array}{l}\text { Working Experience } \\
\text { as Lecturer }\end{array}$} & $\begin{array}{ll}\text { Pearson } & \text { Chi- } \\
\text { Square } & \end{array}$ & 93.686 & 101.309 & 113.915 & 124.144 & 94.924 & 147.095 & 80.854 & 55.984 \\
\hline & Sig. (2-tailed) & 0.659 & 0.756 & 0.948 & 0.758 & 0.877 & 0.243 & 0.693 & 0.752 \\
\hline & Covariance & 0.352 & -0.189 & -0.043 & -0.501 & -0.199 & 0.097 & 0.124 & -0.180 \\
\hline \multirow[t]{3}{*}{$\begin{array}{l}\text { Use of ICT in } \\
\text { Teaching }\end{array}$} & $\begin{array}{ll}\text { Pearson } & \text { Chi- } \\
\text { Square } & \end{array}$ & 127.009 & 96.672 & 127.674 & 137.266 & 101.373 & 149.909 & 76.454 & 79.513 \\
\hline & Sig. (2-tailed) & 0.035 & 0.848 & 0.764 & 0.453 & 0.755 & 0.196 & 0.805 & 0.091 \\
\hline & Covariance & 0.729 & 0.356 & 0.684 & 0.525 & 0.437 & 0.857 & 0.311 & 0.105 \\
\hline \multirow[t]{3}{*}{ Internet at Home } & $\begin{array}{l}\text { Pearson Chi- } \\
\text { Square }\end{array}$ & 68.483 & 99.740 & 132.225 & 180.260 & 201.510 & 104.028 & 58.278 & 65.680 \\
\hline & Sig. (2-tailed) & 0.983 & 0.790 & 0.668 & 0.007 & 0.000 & 0.981 & 0.994 & 0.418 \\
\hline & Covariance & 0.056 & -0.330 & -0.008 & -0.068 & 0.079 & 0.122 & 0.090 & -0.092 \\
\hline \multirow[t]{3}{*}{ Use of PC } & $\begin{array}{l}\text { Pearson Chi- } \\
\text { Square }\end{array}$ & 94.775 & 134.163 & 154.498 & 131.429 & 134.055 & 122.688 & 102.174 & 64.138 \\
\hline & Sig. (2-tailed) & 0.629 & 0.075 & 0.190 & 0.596 & 0.075 & 0.787 & 0.143 & 0.472 \\
\hline & Covariance & 0.796 & 0.318 & 0.752 & 1.000 & 0.469 & 0.606 & 0.001 & 0.393 \\
\hline \multirow[t]{3}{*}{ ICT Training } & $\begin{array}{ll}\text { Pearson } & \text { Chi- } \\
\text { Square } & \end{array}$ & 33.651 & 34.594 & 42.256 & 37.999 & 36.541 & 29.893 & 29.976 & 15.069 \\
\hline & Sig. (2-tailed) & 0.116 & 0.182 & 0.190 & 0.292 & 0.129 & 0.669 & 0.119 & 0.520 \\
\hline & Covariance & 0.332 & 0.525 & 0.051 & 0.191 & 0.538 & 0.216 & -0.185 & 0.103 \\
\hline \multirow[t]{3}{*}{ Training Period } & $\begin{array}{l}\text { Pearson Chi- } \\
\text { Square }\end{array}$ & 63.374 & 90.658 & 103.042 & 94.948 & 61.799 & 69.067 & 53.451 & 40.204 \\
\hline & Sig. (2-tailed) & 0.756 & 0.105 & 0.453 & 0.424 & 0.799 & 0.951 & 0.609 & 0.550 \\
\hline & Covariance & 0.040 & 1.287 & -0.136 & 0.007 & 0.582 & 0.100 & -0.352 & 0.464 \\
\hline \multirow[t]{3}{*}{ Latest Training } & $\begin{array}{l}\text { Pearson Chi- } \\
\text { Square }\end{array}$ & 115.501 & 127.251 & 146.321 & 126.614 & 127.060 & 120.728 & 91.114 & 63.910 \\
\hline & Sig. (2-tailed) & 0.085 & 0.034 & 0.258 & 0.518 & 0.019 & 0.566 & 0.186 & 0.341 \\
\hline & Covariance & -0.116 & -0.522 & -0.076 & -0.181 & -0.340 & 0.374 & -0.222 & 0.220 \\
\hline \multirow[t]{3}{*}{ ICT Knowledge } & $\begin{array}{l}\text { Pearson } \quad \text { Chi- } \\
\text { Square }\end{array}$ & 129.549 & 126.002 & 162.521 & 139.352 & 98.826 & 119.217 & 74.587 & 53.670 \\
\hline & Sig. (2-tailed) & 0.025 & 0.173 & 0.094 & 0.404 & 0.808 & 0.847 & 0.845 & 0.818 \\
\hline & Covariance & 1.476 & 1.106 & 1.680 & 1.108 & 0.777 & 1.444 & 0.636 & 0.114 \\
\hline \multirow[t]{3}{*}{$\begin{array}{l}\text { New ICT } \\
\text { Technologies }\end{array}$} & $\begin{array}{l}\text { Pearson } \quad \text { Chi- } \\
\text { Square }\end{array}$ & 146.971 & 106.084 & 172.696 & 146.444 & 103.883 & 126.772 & 75.006 & 54.851 \\
\hline & Sig. (2-tailed) & 0.002 & 0.640 & 0.032 & 0.254 & 0.695 & 0.703 & 0.837 & 0.786 \\
\hline & Covariance & 1.126 & 0.991 & 1.296 & 1.325 & 0.955 & 1.294 & 0.556 & 0.277 \\
\hline
\end{tabular}


International Journal of Distance Education and E- Learning (IJDEEL) Volume VI- Issue II (June 2021)

\begin{tabular}{l|l|c|c|c|c|c|c|c|c|c}
\hline $\begin{array}{l}\text { ICT } \\
\text { Written/Published }\end{array}$ & $\begin{array}{l}\text { Pearson Chi- } \\
\text { Square }\end{array}$ & 89.899 & 126.240 & 127.035 & 102.970 & 120.635 & 111.574 & 64.020 & 43.795 \\
& Sig. (2-tailed) & 0.756 & 0.169 & 0.776 & 0.984 & 0.272 & 0.983 & 0.975 & 0.975 \\
\cline { 2 - 18 } & Covariance & 0.598 & 1.343 & 1.130 & 0.568 & 0.635 & 0.609 & 0.417 & 0.354 \\
\hline
\end{tabular}

Table b: Associations \& Differences of ICT Utilization with Lecturers' Characteristics

\begin{tabular}{|c|c|c|c|c|c|c|c|}
\hline Areas of ICT & & E-mail & $\begin{array}{c}\text { PC } \\
\text { Security }\end{array}$ & $\begin{array}{c}\text { Lesson } \\
\text { Planning }\end{array}$ & $\begin{array}{c}\text { Teaching } \\
\& \\
\text { Delivery } \\
\end{array}$ & $\begin{array}{l}\text { Technology } \\
\text { Enhanced }\end{array}$ & $\begin{array}{c}\begin{array}{c}\text { Students } \\
\text { needs } \\
\text { Assessment }\end{array} \\
\end{array}$ \\
\hline \multirow[t]{3}{*}{ Qualification } & Pearson Chi-Square & 65.678 & 62.118 & 69.920 & 100.504 & 233.776 & 71.109 \\
\hline & Sig. (2-tailed) & 0.964 & 0.401 & 0.922 & 0.965 & 0.000 & 0.906 \\
\hline & Covariance & 0.565 & 0.019 & 0.227 & 0.339 & -0.530 & -0.059 \\
\hline \multirow[t]{3}{*}{ Last Qualification } & Pearson Chi-Square & 56.659 & 47.864 & 82.584 & 124.091 & 130.277 & 105.422 \\
\hline & Sig. (2-tailed) & 0.996 & 0.871 & 0.643 & 0.581 & 0.427 & 0.099 \\
\hline & Covariance & 0.167 & -0.084 & -0.206 & -0.223 & -1.318 & -0.547 \\
\hline \multirow[t]{3}{*}{ Age } & Pearson Chi-Square & 108.031 & 75.815 & 99.743 & 155.857 & 149.292 & 116.973 \\
\hline & Sig. (2-tailed) & 0.535 & 0.452 & 0.748 & 0.578 & 0.717 & 0.307 \\
\hline & Covariance & 0.001 & -0.048 & 0.122 & -0.260 & -1.211 & -0.558 \\
\hline \multirow[t]{3}{*}{ Gender } & Pearson Chi-Square & 53.293 & 61.692 & 55.832 & 73.755 & 131.219 & 57.608 \\
\hline & Sig. (2-tailed) & 0.870 & 0.050 & 0.810 & 0.955 & 0.010 & 0.760 \\
\hline & Covariance & 0.152 & 0.105 & 0.017 & 0.099 & -0.275 & 0.089 \\
\hline \multirow{3}{*}{$\begin{array}{l}\text { Working } \\
\text { Experience as } \\
\text { Lecturer }\end{array}$} & Pearson Chi-Square & 113.465 & 60.690 & 118.905 & 118.632 & 118.538 & 90.458 \\
\hline & Sig. (2-tailed) & 0.035 & 0.451 & 0.016 & 0.712 & 0.714 & 0.408 \\
\hline & Covariance & -0.110 & -0.061 & -0.192 & -0.025 & -0.722 & -0.261 \\
\hline \multirow{3}{*}{$\begin{array}{l}\text { Use of ICT in } \\
\text { Teaching }\end{array}$} & Pearson Chi-Square & 89.439 & 55.029 & 73.056 & 119.230 & 145.772 & 109.871 \\
\hline & Sig. (2-tailed) & 0.437 & 0.657 & 0.874 & 0.698 & 0.135 & 0.057 \\
\hline & Covariance & 0.527 & 0.267 & 0.116 & 0.258 & -0.067 & -0.028 \\
\hline \multirow[t]{3}{*}{ Internet at Home } & Pearson Chi-Square & 63.016 & 49.412 & 94.540 & 99.554 & 88.328 & 116.882 \\
\hline & Sig. (2-tailed) & 0.980 & 0.834 & 0.298 & 0.970 & 0.997 & 0.021 \\
\hline & Covariance & 0.028 & 0.184 & 0.218 & 0.318 & -0.173 & -0.041 \\
\hline \multirow[t]{3}{*}{ Use of PC } & Pearson Chi-Square & 95.652 & 64.408 & 93.565 & 136.175 & 123.637 & 83.182 \\
\hline & Sig. (2-tailed) & 0.271 & 0.325 & 0.322 & 0.294 & 0.593 & 0.625 \\
\hline & Covariance & -0.142 & 0.259 & -0.167 & -0.281 & -0.318 & -0.429 \\
\hline \multirow[t]{3}{*}{ ICT Training } & Pearson Chi-Square & 36.887 & 17.339 & 15.748 & 28.394 & 36.141 & 17.377 \\
\hline & Sig. (2-tailed) & 0.024 & 0.299 & 0.828 & 0.650 & 0.281 & 0.742 \\
\hline & Covariance & -0.307 & 0.109 & -0.182 & -0.339 & 0.192 & -0.056 \\
\hline \multirow[t]{3}{*}{ Training Period } & Pearson Chi-Square & 65.395 & 51.128 & 76.400 & 111.834 & 75.127 & 51.582 \\
\hline & Sig. (2-tailed) & 0.394 & 0.158 & 0.179 & 0.129 & 0.814 & 0.847 \\
\hline & Covariance & -0.339 & 0.552 & 0.149 & -0.334 & 0.746 & 0.089 \\
\hline \multirow[t]{3}{*}{ Latest Training } & $\begin{array}{l}\text { Pearson } \\
\text { Association }\end{array}$ & 126.447 & 67.124 & 87.382 & 140.718 & 153.161 & 95.841 \\
\hline & Sig. (2-tailed) & 0.002 & 0.147 & 0.499 & 0.209 & 0.022 & 0.266 \\
\hline & Covariance & 0.565 & 0.307 & 0.583 & 0.035 & -0.346 & -0.497 \\
\hline \multirow[t]{3}{*}{ ICT Knowledge } & Pearson Chi-Square & 76.862 & 72.759 & 70.773 & 161.063 & 133.871 & 70.301 \\
\hline & Sig. (2-tailed) & 0.796 & 0.066 & 0.910 & 0.025 & 0.343 & 0.917 \\
\hline & Covariance & 0.410 & 0.527 & 0.504 & 1.079 & 0.608 & 0.694 \\
\hline \multirow{3}{*}{$\begin{array}{l}\text { New ICT } \\
\text { Technologies }\end{array}$} & Pearson Chi-Square & 65.415 & 65.065 & 84.619 & 133.085 & 142.634 & 97.207 \\
\hline & Sig. (2-tailed) & 0.966 & 0.190 & 0.582 & 0.361 & 0.178 & 0.235 \\
\hline & Covariance & 0.311 & 0.463 & 0.323 & 0.445 & 0.432 & 0.564 \\
\hline \multirow{3}{*}{$\begin{array}{l}\text { ICT } \\
\text { Written/Published }\end{array}$} & Pearson Chi-Square & 82.519 & 54.938 & 76.048 & 143.541 & 128.144 & 73.653 \\
\hline & Sig. (2-tailed) & 0.645 & 0.515 & 0.814 & 0.165 & 0.480 & 0.863 \\
\hline & Covariance & 0.191 & 0.573 & 0.401 & 0.999 & 1.075 & 0.860 \\
\hline
\end{tabular}

- Lecturers' qualification aspect was insignificantly associated with all other aspects of ICT utilization, except the use internet (WAN), database and technology enhanced materials. The covariance values were positive except for technology enhanced and student needs assessment aspects with negative values, and those with high values were for e-mail and using internet, 
which indicate the higher difference value among the variables.

- Lecturers' last qualification aspect was insignificantly associated with all other aspects of ICT utilization except spreadsheet. The covariance values were positive except for aspects like computer management, H/W environment, spreadsheet, teaching and delivery and technology enhanced which had negative values, and those with high values were for use of intranet and e-mail, which indicate the higher differences among the variables.

- Lecturers' age aspect was insignificantly associated with all other aspects of ICT utilization. The covariance values were negative except word processing, presentation, using internet (WAN), e-mail and lesson planning with positive values, and those with high values were for word processing and presentation which indicates the higher difference value among the variables.

- Lecturers' gender aspect was insignificantly associated with all other aspects of ICT utilization except using intranet (LAN), PC security and technology enhanced with high significant association value. The covariance values were positive except computer management, H/W environment, using intranet (LAN) and technology enhanced with negative value and those with high values were for student needs assessment and teaching and delivery which indicated higher difference value among the variables.

- Lecturers' working experience aspect was insignificantly associated with all other aspects of ICT utilization except lesson planning and e-mail with high significant association value. The covariance values were negative except computer management, presentation and using internet (WAN) with positive value and those with high values were for computer management which indicates the higher differences among the variables.

- Lecturers' use of ICT in teaching aspect was insignificantly associated with all other aspects of ICT utilization except computer management and students' assessment needs. The covariance values were positive except technology enhanced and student needs assessment with negative value and those with high values were for computer management and presentation which indicates the higher difference value among the variables.

- Lecturers' internet at home aspect was insignificantly associated with all other aspects of ICT utilization except spreadsheet and database with high significant association values. The covariance values were positive except H/W environment, word processing, spreadsheet, technology enhanced and student needs assessment with negative value and those with high values were for student needs assessment, lesson planning, teaching and delivery and presentation which indicates the higher difference value among the variables.

- Lecturers' use of PC (personal computer) aspect was significantly not associated with all other aspects of ICT utilization. The covariance values were positive except e-mail, lesson planning, teaching and delivery, student needs assessment and technology enhanced with negative value and those with high values were for computer management and word processing which indicates the higher difference value among the variables.

- Lecturers' ICT training aspect was insignificantly associated with all other aspects of ICT utilization except word processing. The covariance values were positive except computer management, H/W environment, use of intranet (LAN) and technology enhanced with negative value and those with high values were for student needs assessment and teaching and delivery which indicates the higher difference value among the variables.

- Lecturers' ICT training period aspect was significantly not associated with all other aspects of ICT utilization. The covariance values were positive except word processing, using internet 
(WAN), e-mail and teaching and delivery with negative value and those with high values were for database, technology enhanced and student needs assessment which indicates the higher difference value among the variables.

- Lecturers' Last ICT training aspect was insignificantly associated with all other aspects of ICT utilization except H/W environment, database, e-mail (WAN), technology enhanced and student needs assessment. The covariance values were negative except presentation, use of intranet (LAN), PC security, lesson planning and teaching and delivery with positive value and those with high values were for e-mail and lesson planning which indicates the higher differences among the variables.

- Lecturers' ICT knowledge aspect was insignificantly associated with all other aspects of ICT utilization except teaching and delivery and computer management. The covariance values were positive and those with high values were for using internet (WAN) and database which indicates the higher differences among the variables.

- Lecturers' awareness about new ICT technologies aspect was significantly not associated with all other aspects of ICT utilization except computer management and word processing. The covariance values were positive and those with high values were for using internet (WAN) and student needs assessment which indicates the higher differences among the variables.

- Lecturers' ICT written / published aspect was significantly not associated with all other aspects of ICT utilization. The covariance values were positive value and those with high values were for student needs assessment and teaching and delivery which indicate the higher differences among the variables.

In general, the association among lecturers' demographics and fourteen areas of ICT utilization showed the association value. Most of the covariance values were positive and less was with the value of higher differences in conjunction with ICT utilization in instruction in selected universities of Pakistan.

\section{Discussion}

As for research question mentioned above, the relationships and differences among levels of ICT utilization in instruction and lecturers' characteristics, this study found that lecturers' qualification was significantly associated with aspects of ICT utilization in instruction such as use of Internet, technology enhanced and database.

This shows that the lecturers with high professional qualification were very good in using search engines and logical operators for information in their instruction. They were effectively practicing discussion, instructional strategies online, web-based meeting tools to facilitate instruction in selected universities in Pakistan.

The study also showed the significant associations among gender and internet use, PC security, and technology enhanced media. In a male dominated society such as Pakistan, the male lecturers were availing of more ICT facilities to utilize in instruction as compared to the female lecturers.

A significant association was also found among the last ICT training for instruction and $\mathrm{H} / \mathrm{W}$ environment and e-mail. It reveals that the lecturers who received latest ICT training for instruction were good in terms of managing and handling ICT tools and hardware like connecting computers with peripherals, using scanner, digital camera / camcorder, copyrights, and health or safety issues in computing. 


\section{Summary}

This study had established ICT utilization by lecturers with respect to the respondent's variables like, professional qualification, last professional qualification, age, working experience, personal computer use at home, experience in computer use, frequency of ICT use, ICT training, Training duration, ICT knowledge, awareness about ICT, ICT written/ published in university. Hence, it was proved that these variables were capable of increasing ICT utilization in instruction among lecturers in universities.

The factors stated such as ICT expenditures, ICT training, fear of ICT were the critical factors affecting ICT utilization in instruction among lecturers in universities of Islamabad. These factors are important source of predictors in the failure or success of ICT utilization in universities of Islamabad. Further this study suggested that lecturers needed a revised formal information \& communication technology education.

As a concluding remark, the successful ICT utilization in instruction among lecturers needs the concerted efforts of all stakeholders. The fullest co-operation and support from the university administration, all concerned departments, and continuous training to update lecturers' ICT skills can arrest the deteriorating quality of education and assist to enhance the ICT utilization in instruction among lecturers in universities of Islamabad.

\section{References}

Altun, E. H. (1996). Information technology in developing nations: A study of lecturers' attitudes and expertise with reference to Turkish teacher education. Technology, Pedagogy and Education, 5(3), 185-205.

Al-Zahrani, R. S. (2000). Perceptions concerning information technology (IT) innovations and IT training in university in Saudi Arabia. Ph.D. dissertation, Florida State University.

Barker, P. (2002). On being an online tutor. Innovations in Education and Teaching International, 39(1), 3-13.

Chen, Li-Ping (1995). A case study of network organization, performance and librarians' attitudes in Taiwan, R.O.C. (China). Unpublished doctoral dissertation, The Florida State University).

Davis, F. D. (1989). Perceived usefulness, perceived ease of use, and user acceptance of information technology. MIS Quarterly, 13(3), 319-340.

Henerson, M. E., Morris, L. L., \& Fitz-Gibbon, C. T. (1987). How to measure attitudes. Newbury Park, CA: Sage.

Jones, A., \& Preece, J. (2006). Online communities for teachers and lifelong learners: A framework for comparing similarities and identifying differences in communities of practice and communities of interest. International Journal of Learning Technology, 2(2), 112-137.

Khan, N. S., \& D. Bawden. (2005). Community informatics in libraries in Pakistan: Current status, future prospects. New Library World 106 (1218/1219): 532-540.

Pickard, A. J. (2007). Research methods in information. London, UK: Facet.

Thomson Scientific. (2007). ISI Web of Knowledge. Available at http://isiknowledge.com/ 
International Journal of Distance Education and E- Learning (IJDEEL) Volume VI- Issue II (June 2021)

Wilkins, K. G. (1999). Development Discourse on Gender and Communication in Strategies for Social Changes. Journal of Communication, 49(1), 46-68. 